\title{
Micrographia
}

\section{The Ovariol Morphology and Ultrastructure of Poecilimon ataturki Ünal, 1999 (Orthoptera, Tettigoniidae) and the Histochemical Features of the Yolk Granules}

\author{
Damla Amutkan Mutlu ${ }^{1 *}$ (D), Irmak Polat ${ }^{2}$ (D) and Zekiye Suludere ${ }^{1}$ (D) \\ ${ }^{1}$ Faculty of Science, Department of Biology, Gazi University, Ankara 06500, Turkey and ${ }^{2}$ Faculty of Science, Department of Biology, Çankırı Karatekin University, \\ Çankırı 18100, Turkey
}

\begin{abstract}
This study presents the oocyte development of Poecilimon ataturki Ünal, 1999 (Orthoptera, Tettigoniidae) with histology, morphology, and histochemistry by using a stereomicroscope, a light microscope, a scanning electron microscope, and a transmission electron microscope. The ovary in this species is a panoistic type which contains many ovarioles which consist of terminal filament, germarium, and vitellarium. Germarium is the region that has undifferentiated cells which generate the oocytes and follicular cells. In the vitellarium region, yolk granules start to cover the whole oocyte. In histochemical studies, to determine the content of the yolk granules, proteins, and carbohydrates in oocytes were treated with a bromophenol blue (BPB) method, a mercury bromophenol blue (mBPB) method, and a periodic acid Schiff (PAS) method, respectively. As a result of these methods, the yolk granules gave positive results in ovariole sections treated with the $\mathrm{PAS}$ and the $\mathrm{BPB}$, while the $\mathrm{mBPB}$ staining was negative.
\end{abstract}

Key words: bromophenol blue, oocyte, PAS, transmission electron microscope, yolk granules

(Received 17 December 2020; revised 11 February 2021; accepted 23 April 2021)

\section{Introduction}

The female reproductive system in insects consists of a pair of ovaries which consist of ovarioles, a pair of lateral oviducts, and a genital chamber. Each ovary continues with a canal called a lateral oviduct where the mature egg moves forward to be left out and the lateral oviducts come together to form a common oviduct of ectodermal origin (Viscuso et al., 1999; Lange, 2009; Klowden, 2013; Pappalardo et al., 2016). Besides all these main reproductive organs such as spermatheca (receptaculum seminis) and reproductive glands, there are some other auxiliary structures that help reproduction in female insects which play a role in transfer and protection of the gametes (Nandchahal, 1972; Giuffrida et al., 1996; Sturm \& Pohlhammer, 2000; Lange, 2009; Brundo et al., 2011; Sturm, 2012; Masci et al., 2015; Pappalardo et al., 2016).

Ovarioles are the units of ovaries where the oocyte grows and developed. The anterior end of the ovariole has a filamentous structure that connects the ovariole to the body wall (Klowden, 2013; Polat, 2016). The germarium layer containing germ cells comes after the terminal filament. As germ cells grow and develop, they move toward the anterior end of the ovary. First, the mature eggs are kept at the lateral

\footnotetext{
*Author for correspondence: Damla Amutkan Mutlu, E-mail: damlamutkan@gazi. edu.tr

Cite this article: Amutkan Mutlu D, Polat I, Suludere Z (2021) The Ovariol Morphology and Ultrastructure of Poecilimon ataturki Ünal, 1999 (Orthoptera, Tettigoniidae) and the Histochemical Features of the Yolk Granules. Microsc Microanal 27, 650-657. doi:10.1017/S1431927621000404
}

oviduct until the female finds a suitable place for oviposition. Then, the female pushes the mature egg toward the genital chamber by the contraction of the muscles in the lateral oviduct for oviposition (Lange, 2009; Polat, 2016). Meanwhile, the female releases the sperm which is from the male insect and stores the sperm in spermatheca after mating, and thus, fertilization is achieved (Lange, 1990, 2009; Giuffrida \& Rosati, 1993; Viscuso et al., 1999; Vahed, 2003; Sturm, 2005; Brundo et al., 2011; Polat, 2016).

In many insect species like Sitophilus granarius (L.) (Coleoptera, Curculionidae), the females make holes in grains to laying eggs in the holes. Then, the females release secretion to create a kind of plug composed of mucous material which has a role in sticking the eggs to each other and secures them from the grain infestation. This mucous material is secreted by the activity of the female reproductive gland. Likewise, the female reproductive glands have some duties on showing antibacterial properties, carrying sperms into the spermatheca, and producing some materials of the egg chorion (Gaino \& Fava, 1995; Sturm, 2012; Masci et al., 2015; Gnatzy et al., 2018).

Although many insect species have the main and accessory reproductive organs, their morphological and histological structure, number, and ultrastructure vary between ordos, families, and species. For that reason, these features are very important taxonomically (Nandchahal, 1972; Lange, 2009; Brundo et al., 2011; Klowden, 2013; Masci et al., 2015; Polat, 2016).

Ordo Orthoptera generally includes phytophagous insects. Some species of Orthoptera can create swarms that can increase their populations very quickly in a short time and migrate over

(C) The Author(s), 2021. Published by Cambridge University Press on behalf of the Microscopy Society of America. This is an Open Access article, distributed under the terms of the Creative Commons Attribution licence (http://creativecommons.org/licenses/by/4.0/), which permits unrestricted re-use, distribution, and reproduction in any medium, provided the original work is properly cited. 
long distances. Therefore, they can cause large losses in agricultural fields and crops. For that reason, ordo Orthoptera forms a group that has an economical importance. In this context, in order to combat invasive species, the structures of these species must be well known (Mead et al., 1988; Şahin et al., 2004; Karaca et al., 2006; Willis et al., 2010; Y1lmaz et al., 2012; Polat, 2016).

Poecilimon, a genus belonging to the Tettigoniidae family (Orthoptera), lives on the shrubs in the open areas at the edges of coniferous forests. Genus Poecilimon has 134 species identified in most of the South-Eastern Europe, in Anatolia, and in the Caucasus region. The individuals belonging to this genus have generally green color and short wings that enable them to have very little displacement. The knowledge about the biology and structure of Poecilimon ataturki Ünal, 1999 (Orthoptera, Tettigoniidae) which is an endemic species in Turkey, is very limited in the literature (Sevgili, 2001; Heller, 2004; Heller \& Sevgili, 2005; Tazegül \& Önder, 2012; Polat, 2016). In line with all this information, the main goal of this study is to reveal the morphological, histological, and cytological structure of the ovaries of $P$. ataturki.

\section{Material and Methods}

The field survey of $P$. ataturki was done in Bolu province, Hamidiye Village in July 2019, and 10 female P. ataturki individuals were taken to the laboratory after collecting by hand on the shrubs or by sweep net. $P$. ataturki females were dissected, and the ovaries and eggs were taken out from the body cavity. Then, the ovaries were cleaned, photographed under the stereomicroscope, and prepared for the light microscope (LM), the scanning electron microscope (SEM), and the transmission electron microscope (TEM) examination.

For the LM studies, the ovaries were dehydrated in the ascending series of ethanol and embedded in paraffin blocks. The sections at $6 \mu \mathrm{m}$ thickness were cut with a microtome and stained with a routine histological staining procedure (Hematoxylin-Eosin, H\&E) and Mallory's trichrome staining. They were also stained with Periodic Acid Schiff (PAS) to mark neutral mucosubstances, and Bromophenol Blue (BPB) and Mercury Bromophenol Blue (mBPB) were used to reveal the protein in the oocytes. Then, the slides were examined with an LM (Olympus BX51) and photographed.

For the SEM examinations, the ovaries were first dehydrated and then dried with a critical point dryer (Polaron CPD 7501). The dried specimens of the ovaries were bonded on the SEM stubs and coated with gold with a sputter coater (Polaron SC 502). Afterwards, the ovaries were examined in the SEM (JEOL JSM 6060 LV) and images were recorded.

For the TEM examinations, the ovaries were first taken in 5\% glutaraldehyde for pre-fixation, and then, they were post-fixed in $1 \% \mathrm{OsO}_{4}$. After rinsing in phosphate buffer, the ovaries were dehydrated in the ascending series of ethanol and blocked in Araldite. Ultra-thin sections at $0.1 \mu \mathrm{m}$ thickness were cut with an ultramicrotome and stained with uranyl acetate and lead citrate. Finally, the sections were imaged with the TEM (JEOL JEM 1400) and photographed.

\section{Results}

The female reproductive system in $P$. ataturki is composed of a pair of ovaries, a pair of lateral oviducts, a median (common) oviduct, and a receptaculum seminis (spermatheca) (Figs. 1, 2). Ovaries are located dorsolaterally in the body cavity, and a

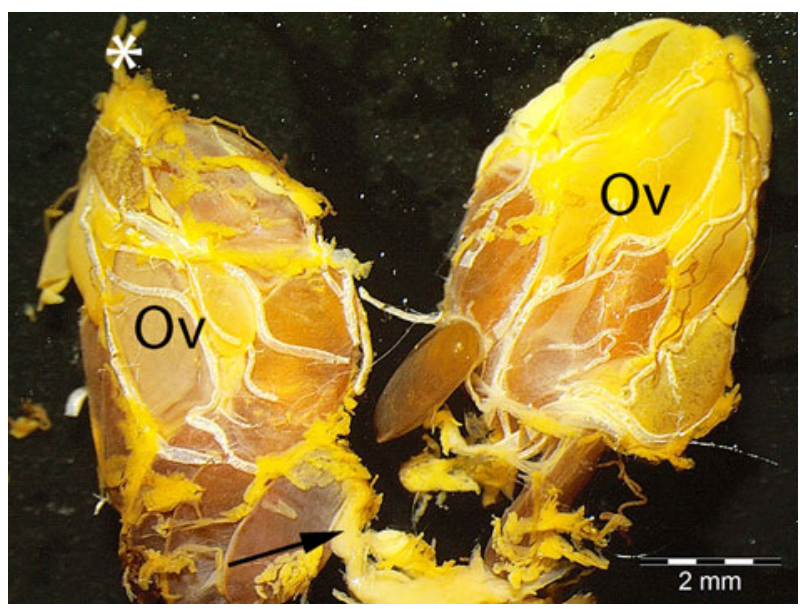

Fig. 1. The general structure of the female reproductive system in P. ataturki. Ov, ovarium; $\rightarrow$, lateral oviduct; ${ }^{*}$, terminal filament (Stereomicroscope image, scale bar $=$ $2 \mathrm{~mm})$.

group of the filamentous structure composed of terminal filaments connect the ovaries to the body wall. Lateral oviducts are the canals where the mature eggs are expelled from the ovaries, and both lateral oviducts open to the median oviduct (Fig. 2). The receptaculum seminis which has a duty on storing the sperm until oviposition after copulation is also connected to the median oviduct (Fig. 2).

Each ovary contains approximately 9-12 panoistic type ovarioles (Figs. 1-3). The ovaries are covered by a meshwork called as epithelial sheath composed of the muscle tissue (Fig. 4).

The ovarioles are composed of three regions called terminal filament, germarium, and vitellarium. The terminal filaments are filamentous structures at the distal side of the ovariole that come together and connect the ovariole to the body wall (Figs. $1,3)$. Germarium is the region that has undifferentiated cells which generate the oocytes and follicular cells (Fig. 5). There is a layer of interfollicular cells at the base of the germarium (Fig. 5). In the LM and TEM micrographs, the cells of the interfollicular layer look elongated and multilayered with elongated nucleus (Figs. 6, 7). Vitellarium comes after germarium and is

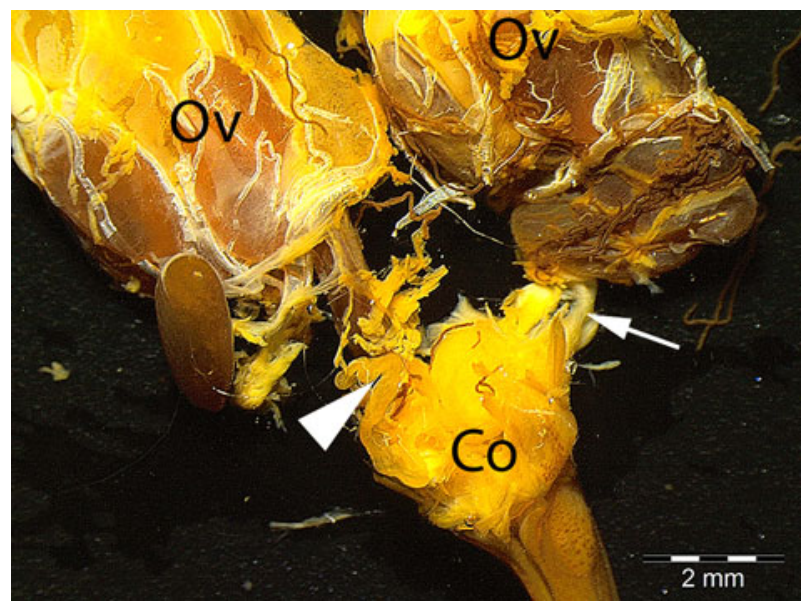

Fig. 2. The general structure of the female reproductive system in $P$. ataturki. Ov, ovarium; $\rightarrow$, lateral oviduct; $\rightarrow$, receptaculum seminis (spermatheca); Co, common (median) oviduct (Stereomicroscope image, scale bar $=2 \mathrm{~mm}$ ). 


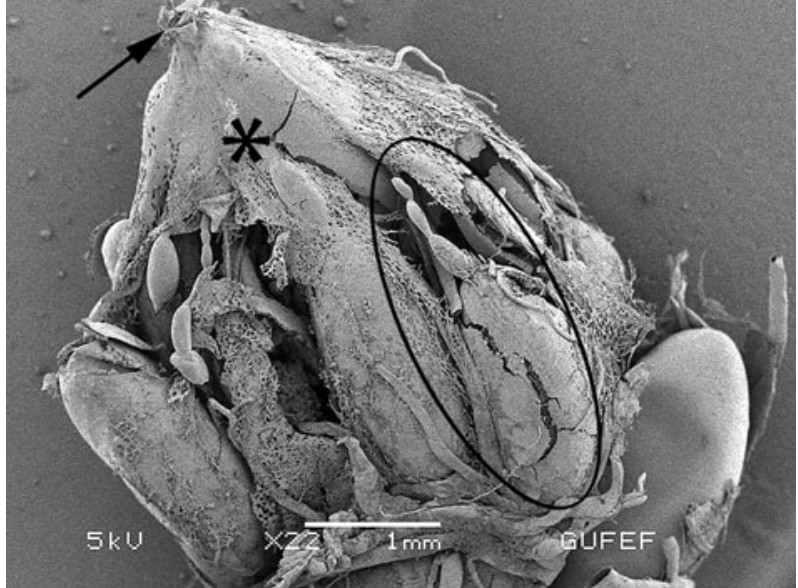

Fig. 3. The general structure of an ovarium. Encircled: ovariol; $\rightarrow$, terminal filament; $;$, epithelial sheath (SEM image, scale bar $=1 \mathrm{~mm}$ ).

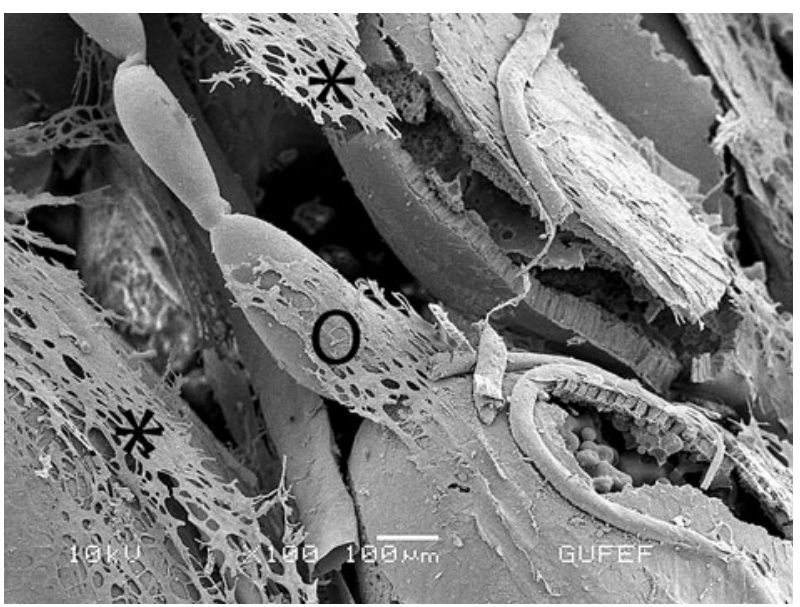

Fig. 4. The ovariol $(0)$ covered with the epithelial sheath $\left(^{*}\right)$ (SEM image, scale bar $=$ $100 \mu \mathrm{m})$.

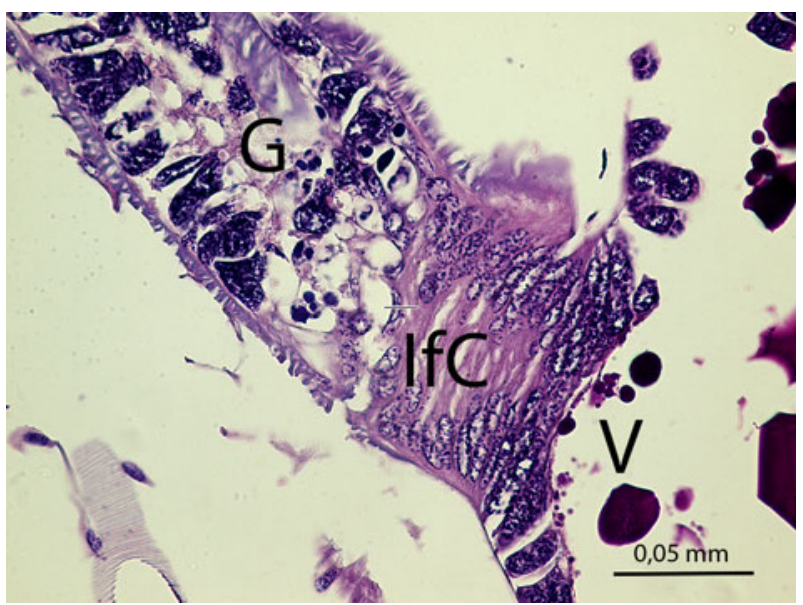

Fig. 5. The longitudinal section of the germarium region and interfollicular area of the ovariol. G, germarium; IfC, interfollicular cells; V, vitellarium (LM image, H\&E, scale bar $=0.05 \mathrm{~mm}$ )

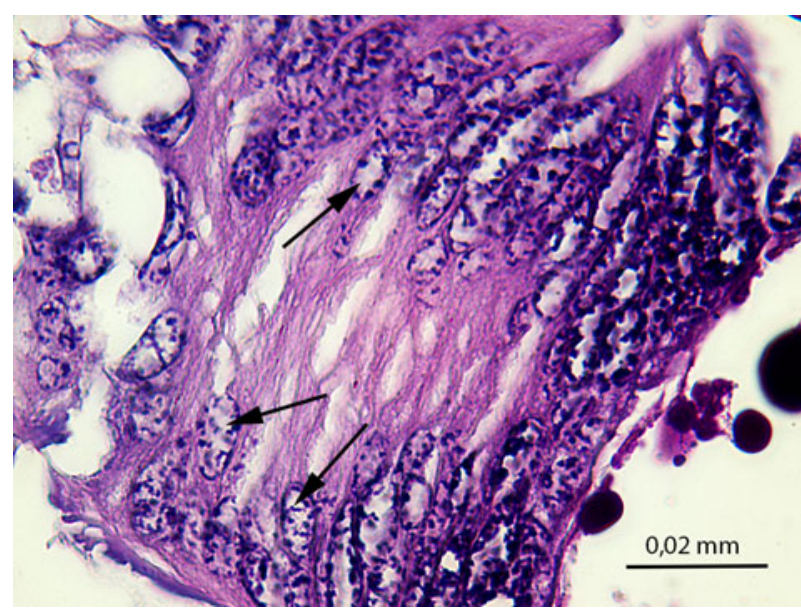

Fig. 6. The longitudinal section of the interfollicular cells with the elongated nucleus $(\rightarrow)$ (LM image, H\&E, scale bar $=0.02 \mathrm{~mm}$ ).

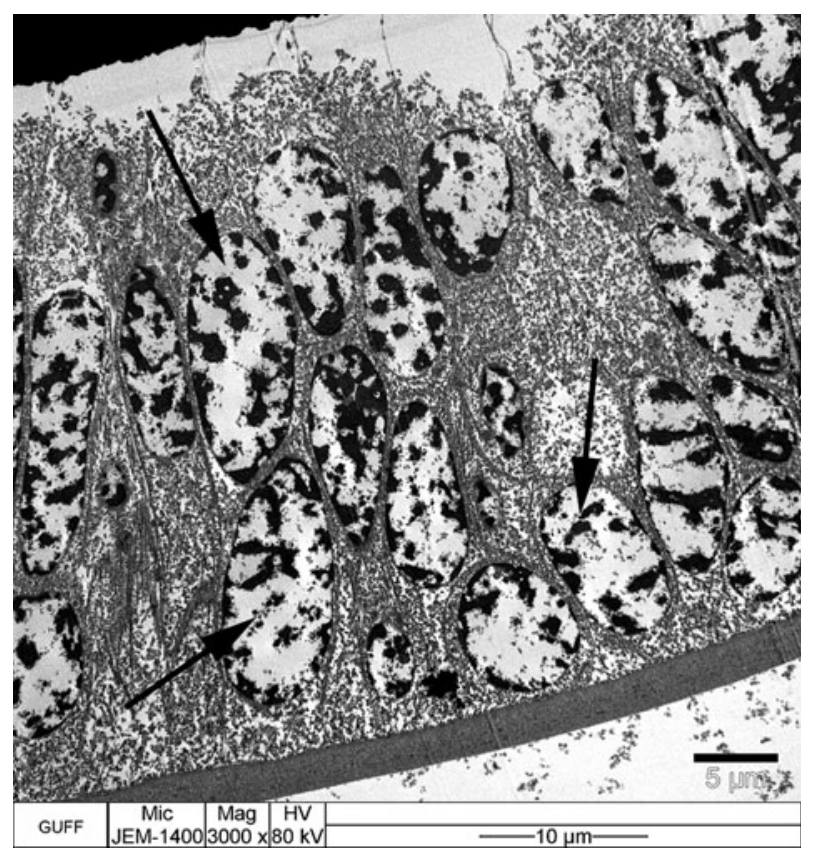

Fig. 7. The longitudinal section of the interfollicular cells with the elongated nucleus $(\rightarrow)$ (TEM image, scale bar $=5 \mu \mathrm{m}$ ).

characterized by a series of ovariole follicles with oocytes in different developmental stages (Fig. 8). Vitellarium consists of three developmental stages including previtellogenesis, vitellogenesis, and choriogenesis. At the end of the choriogenesis, the oocyte completes its development.

At the previtellogenesis, the first stage of the vitellarium, the thin follicle cell layer encircles the oocyte (Figs. 8-10). The follicle cells are squamous and single layered, and the nuclei occupy a large part of the follicle cells (Fig. 10). In the previtellogenic stage, the yolk granules and lipid droplets are not yet present in the oocytes.

The second stage of the vitellarium is the vitellogenesis which comes after the previtellogenesis. This stage of development is characterized by the yolk granules produced without the chorion in the oocyte (Figs. 11, 12). Yolk granules begin to be secreted by 


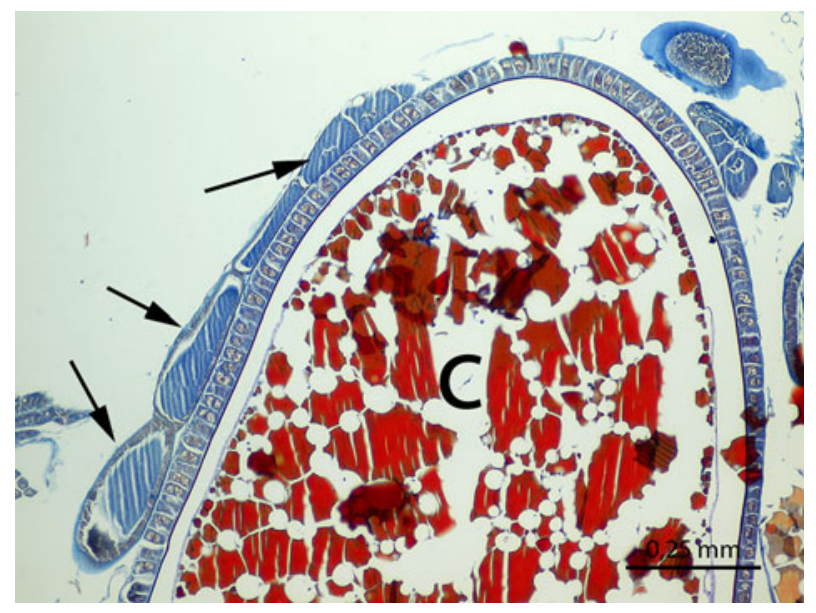

Fig. 8. The previtellogenic stage with the different developmental stages $(\rightarrow)$ and the choriogenic stage (C) (LM image, Mallory's trichrome staining, scale bar $=0.25 \mathrm{~mm}$ ).

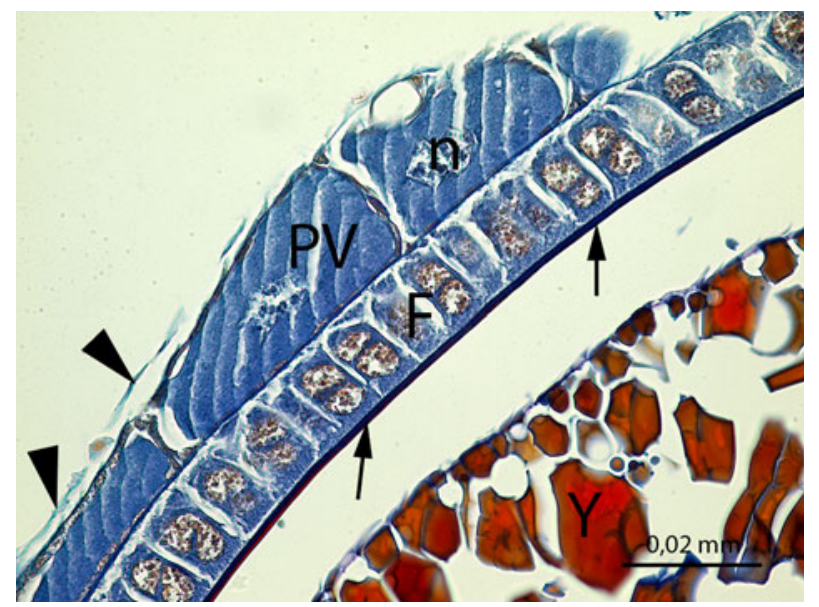

Fig. 9. The detail of the previtellogenic stage and the choriogenic stage. PV, previtellogenic stage; $F$, follicle cells of the choriogenic stage; $n$, nucleus of the oocyte in the previtellogenic stage; $Y$, yolk granules; $\rightarrow$, chorion of the egg; - epithelial sheath (LM image, mallory's trichrome staining, scale bar $=0.02 \mathrm{~mm}$ ).

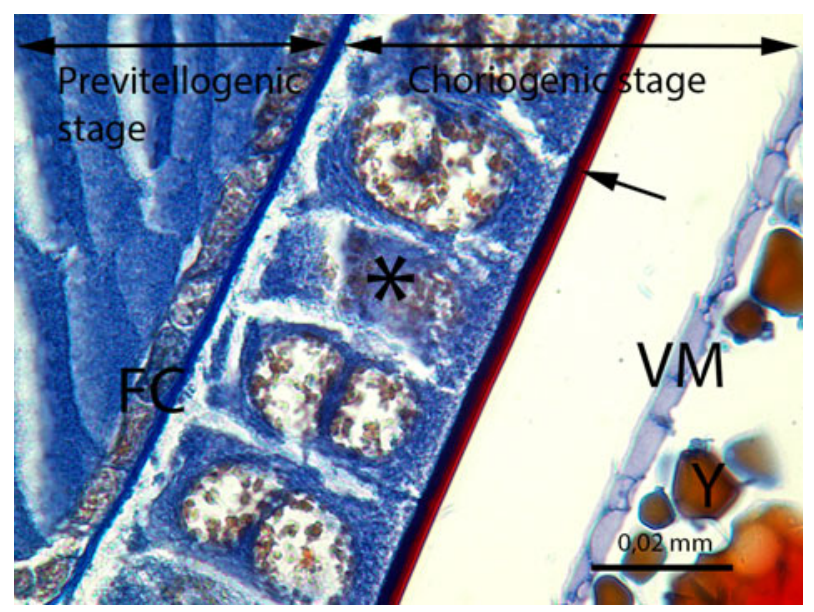

Fig. 10. The developing oocyte in the previtellogenic stage and the oocyte in the choriogenic stage. FC, follicle cells of the previtellogenic stage; ${ }^{*}$, follicle cells of the choriogenic stage; $\rightarrow$, chorion of the egg; VM, vitelline membrane; Y, yolk granules (LM image, Mallory's trichrome staining, scale bar $=0.02 \mathrm{~mm}$ ).

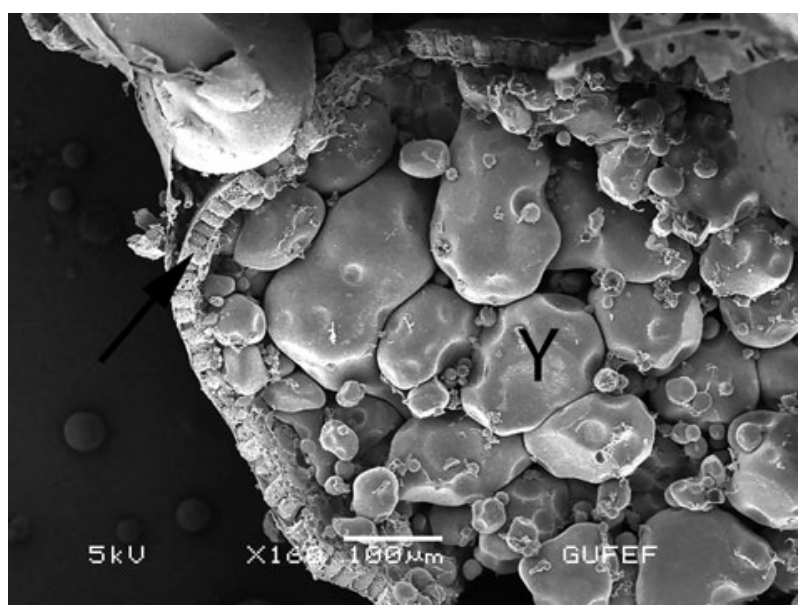

Fig. 11. The longitudinal section of the oocyte in the vitellogenic stage. Y, yolk granules; $\rightarrow$, follicle cells of vitellogenic stage (SEM image, scale bar $=100 \mu \mathrm{m}$ ).

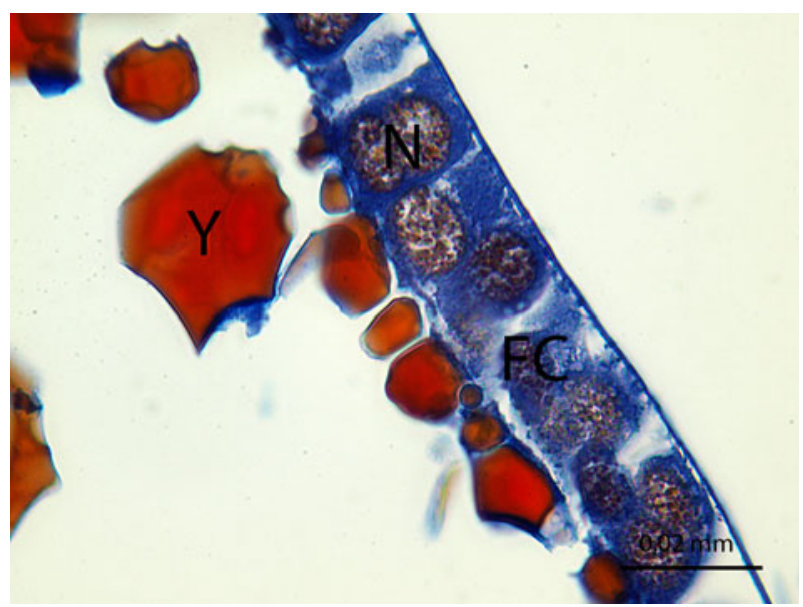

Fig. 12. The vitellogenic stage in the ovariol without the chorion. FC, follicle cells; $Y$, yolk granules; N, nucleus (LM image, Mallory's trichrome staining, scale bar= $0.02 \mathrm{~mm}$ ).

follicle cells at the beginning of this stage, and the oocyte is full with yolk granules of different sizes and shapes at the end of the vitellogenic stage (Fig. 11). The follicle cells in the vitellogenic stage are single-layered cuboidal-columnar cells (Figs. 13-15). There are some gaps in different wideness between the follicle cells called intercellular spaces (Figs. 13, 14). As intercellular spaces can completely separate the lateral membranes of two follicle cells, they can also be seen in enlarged areas in the lateral membranes in some regions (Figs. 14, 15). In TEM micrographs of the vitellogenic stage, we can observe the large nucleus of the columnar follicle cells. The two-lobed nucleus, which appears to be knuckled in the middle, occupies a large part of the follicle cell. Euchromatin regions are generally predominant in the nucleus (Figs. 15, 16). That the cytoplasm of the follicle cells has numerous granulated endoplasmic reticulum cisterns that can be observed in Figure 17.

The last stage of the vitellarium is called as choriogenesis. With the choriogenesis, the vitelline membrane and chorion encircle oocyte are formed (Fig. 10). Thus, the oocyte development is completed and the mature oocyte is transferred from the ovariole into the lateral oviduct. In Figure 18, two layers of the mature 


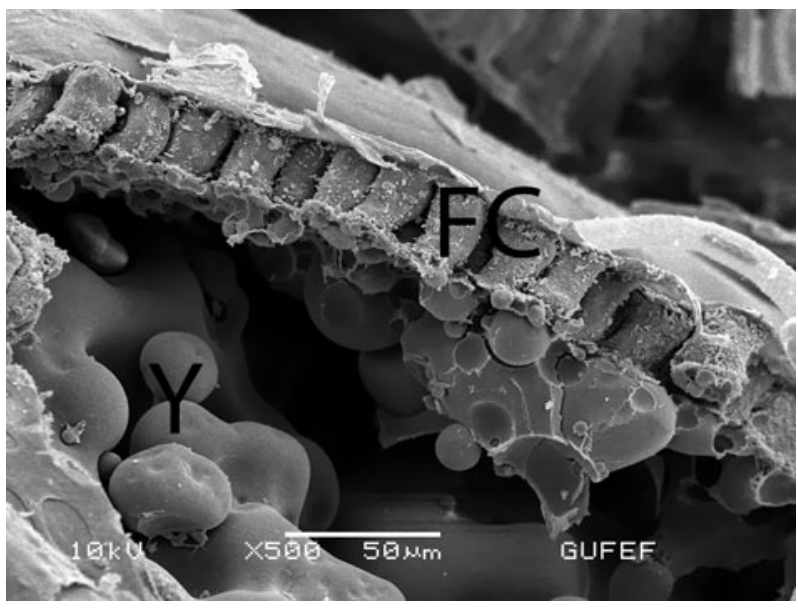

Fig. 13. The vitellogenic stage in the ovariol without the chorion. $\mathrm{FC}$, follicle cells; $\mathrm{Y}$, yolk granules (SEM image, scale bar $=50 \mu \mathrm{m}$ )

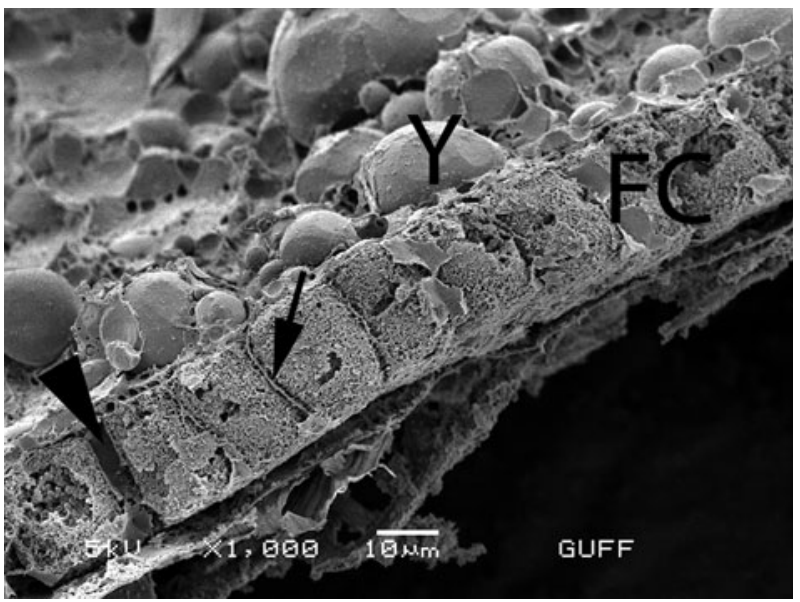

Fig. 14. The vitellogenic stage in the ovariol. FC, follicle cells; $\mathrm{Y}$, yolk granules; intercellular space; $\rightarrow$, lateral membrane of the follicle cell (SEM image, scale bar $=10 \mu \mathrm{m})$.

oocyte chorion, the endochorion and the exochorion, can be distinguished in the lateral oviduct.

According to the results of histochemical studies, it is seen that some of the yolk granules in the ooplasm were stained purple in sections treated with PAS stain. The PAS-positive areas of the yolk in the ooplasm are indicated in Figures 19 and 20. The positive reaction of the PAS stain with carbohydrates of the yolk granules began to be seen in the vitellogenesis stage of oogenesis (Fig. 19). In sections treated with $\mathrm{BPB}$, it is seen that some of the yolk granules are stained blue in the choriogenesis stage of oogenesis (Fig. 21). On the other hand, there was no reaction in the sections treated with $\mathrm{mBPB}$ (Fig. 22).

\section{Discussion}

When ovary morphology in $P$. ataturki was examined, the first striking and important difference is the number of ovarioles with the exception of color, shape, or size. The number of ovarioles in insects may vary between species in the same order, even in the same family. In Baeacris punctulatus (Thunberg, 1824) (Orthoptera, Acrididae), the ovaries are made up of 10 ovarioles

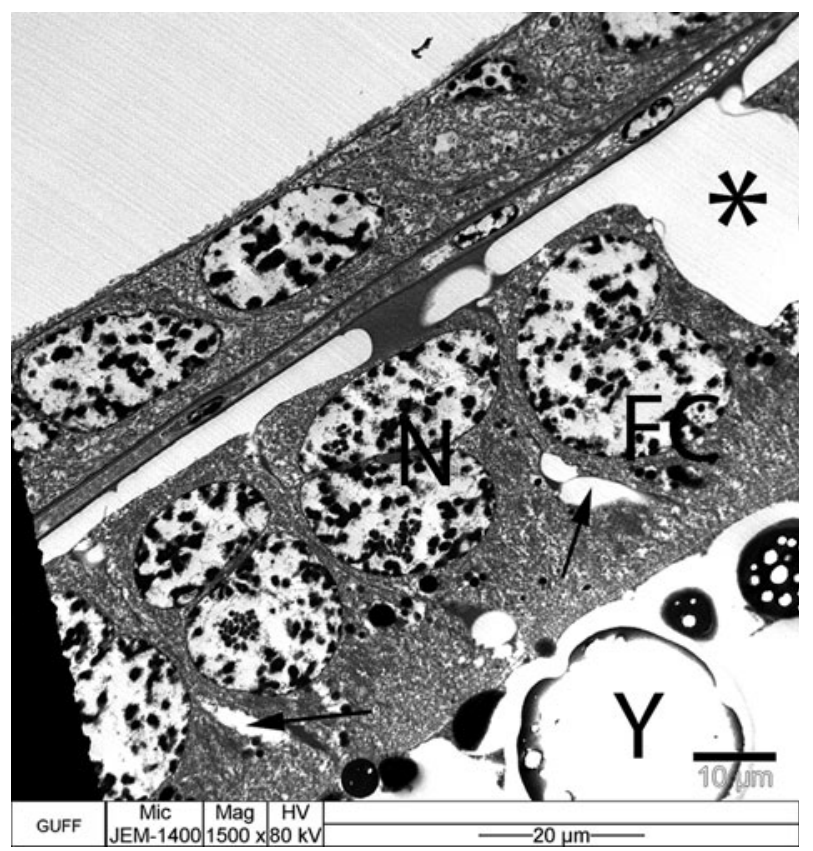

Fig. 15. The vitellogenic stage in the ovariol. FC, follicle cells; $\mathrm{Y}$, yolk granules; $\mathrm{N}$ nucleus; ${ }^{*}$, intercellular space; $\rightarrow$, enlarged areas between two lateral membranes (TEM image, scale bar $=10 \mu \mathrm{m}$ ).

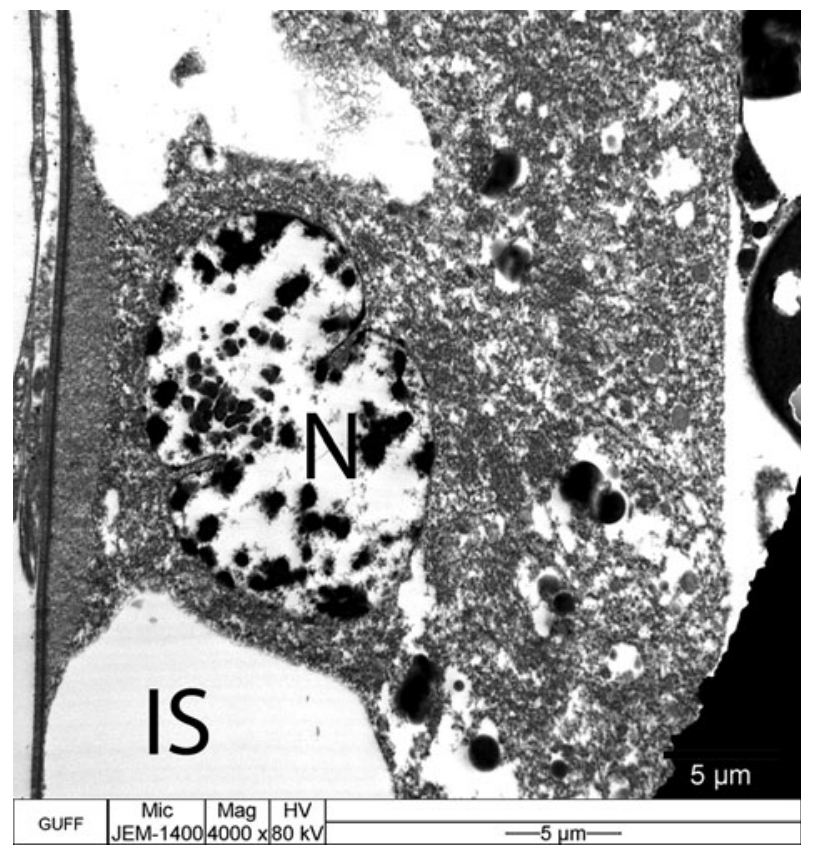

Fig. 16. The follicle cell with the two-lobed nucleus $(\mathrm{N})$ in the vitellogenic stage. IS intercellular space (TEM image, scale bar $=5 \mu \mathrm{m}$ ).

(Michel \& Terán, 2005). Gryllodes sigillatus (Walker, 1869) (Orthoptera, Gryllidae) has 120-150 ovarioles in the female reproductive organ (Nandchahal, 1972). This number changes between 9 and 12 ovarioles in $P$. ataturki. Ovariole number is a powerful determinant of fertility rate (Taylor \& Whitman, 2010; García-Navas et al., 2017). The average number of the ovarioles and eggs generally show a strong relationship between insect body size and the number of ovarioles in grasshoppers 


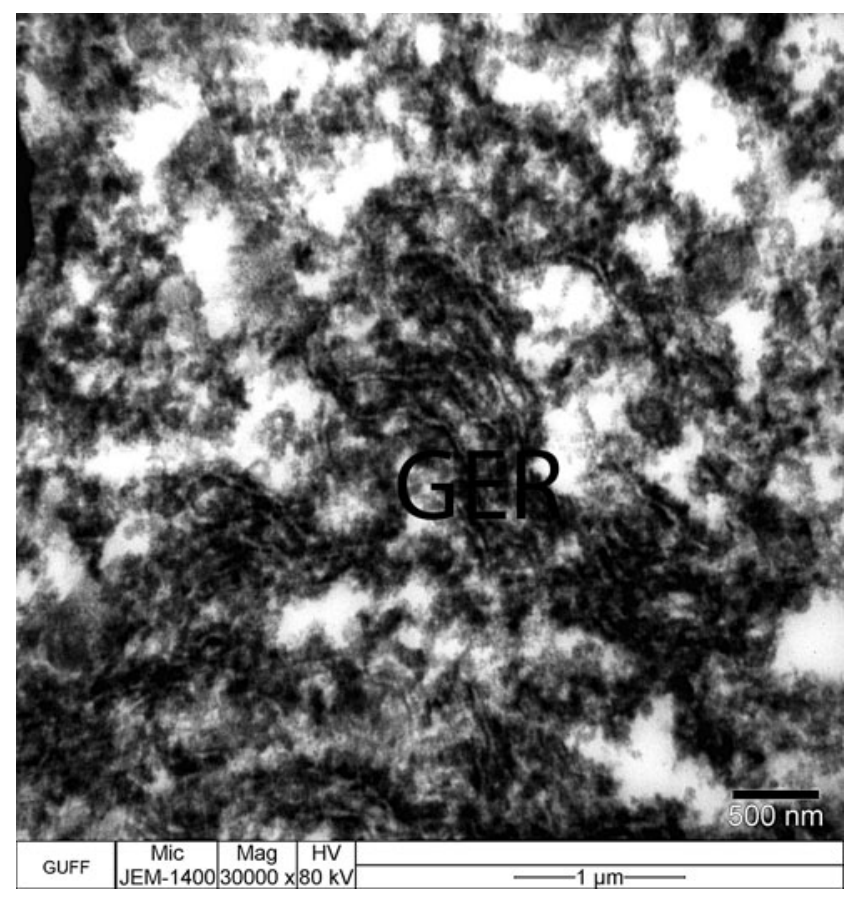

Fig. 17. The cytoplasm of the follicle cell of the choriogenic stage with the granulated endoplasmic reticulum (GER) (TEM image, scale bar $=500 \mathrm{~nm}$ ).

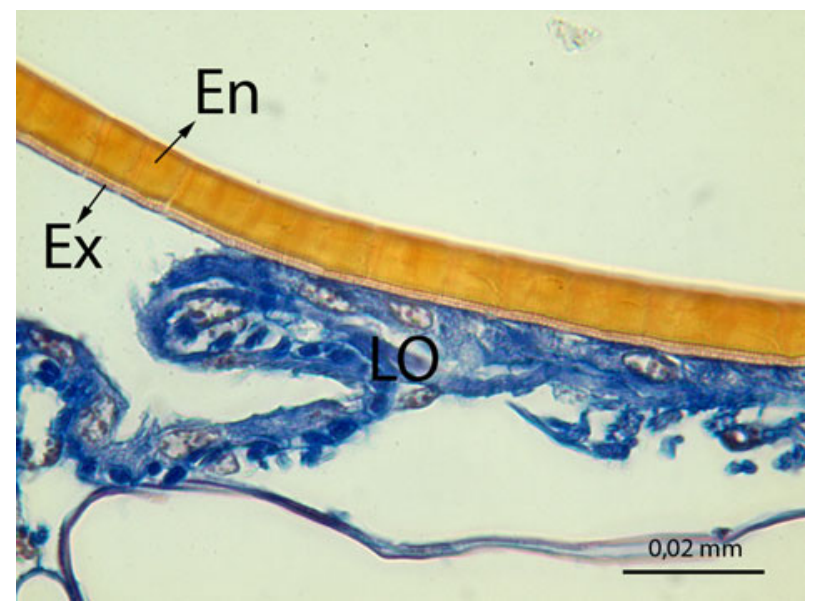

Fig. 18. The longitudinal section of the lateral oviduct (LO). Ex, exochorion; En, endochorion (LM image, H\&E, scale bar $=0.02 \mathrm{~mm}$ ).

(Schultner et al., 2012). Therefore, female individuals with more ovarioles can produce a great number of eggs at each fertilization. However, the reproductive capacity of a female individual can be influenced by a number of other factors, such as the environmental factors, feeding style, or genetic factors.

In this paper, the ovarian histology was also mentioned in addition to its morphology. The Ovarian histology in P. ataturki was found similar to the ovarian histology of other studied species belonging to the order Orthoptera. No significant difference was found in the cellular structure. The subject which is wanted to be highlighted in this study is the content of the yolk granules in the oocyte cytoplasm (ooplasm).

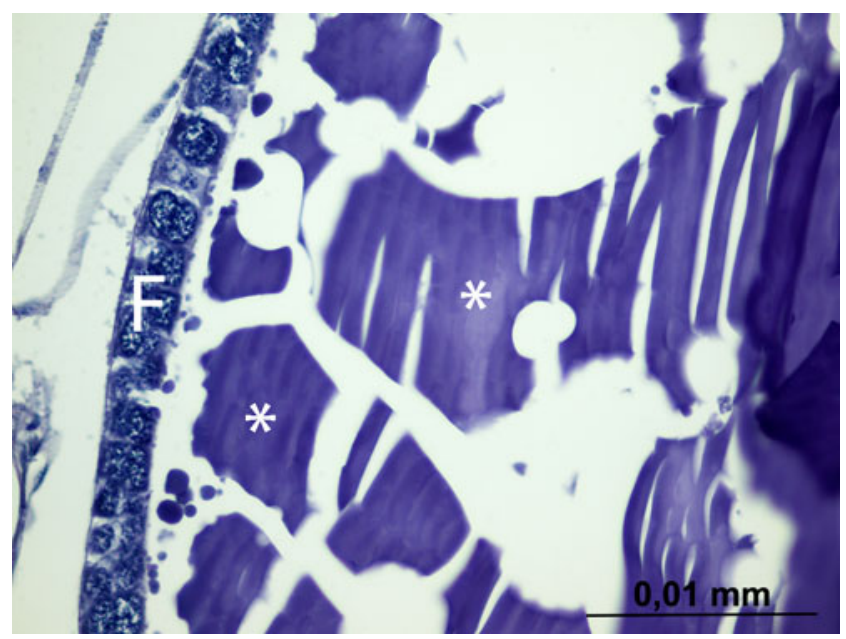

Fig. 19. The PAS staining of the vitellogenic stage of the ovariol. *, PAS-positive carbohydrate yolks; F, follicular epithelium (LM image, PAS staining, scale bar = $0.01 \mathrm{~mm})$.

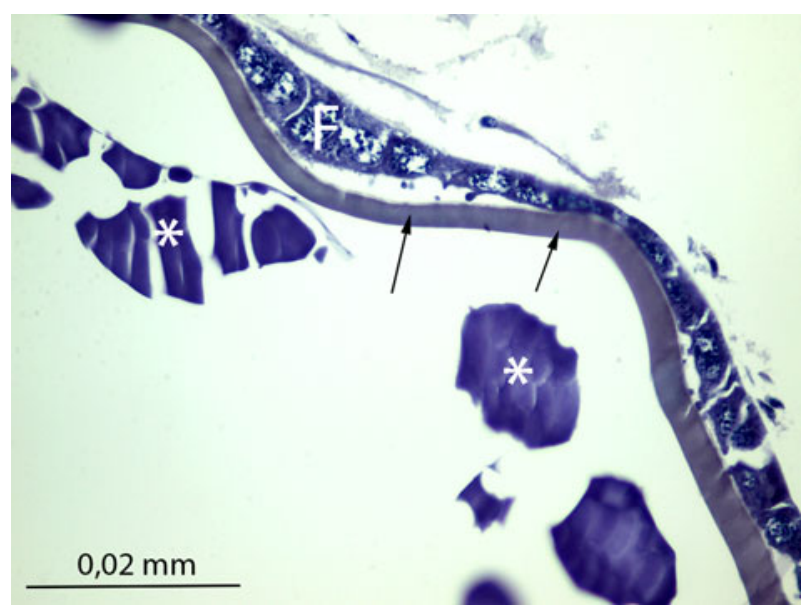

Fig. 20. The PAS staining of the choriogenic stage of the ovariol. *, PAS-positive carbohydrate yolks; F, follicular epithelium; arrows, chorion (LM image, PAS staining, scale bar $=0.02 \mathrm{~mm}$ ).

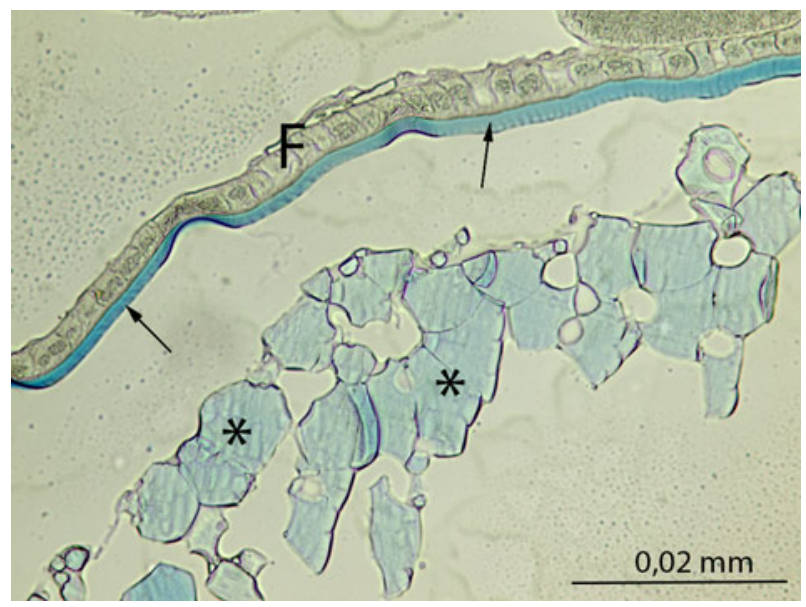

Fig. 21. The BPB staining of the choriogenic stage of the ovariol. *, BPB positive protein yolks; F, follicular epithelium; arrows, chorion (LM image, BPB staining, scale bar $=0.02 \mathrm{~mm}$ ). 


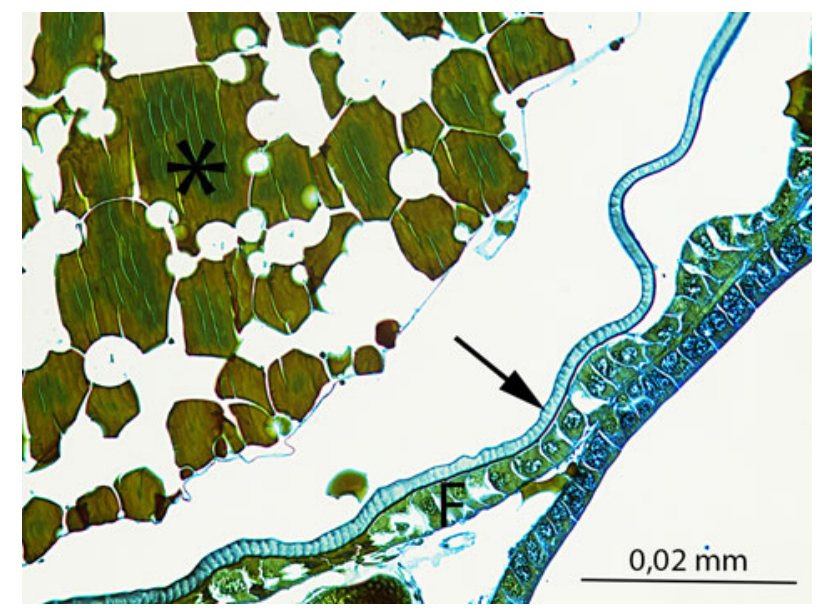

Fig. 22. The negative $\mathrm{mBPB}$ staining of the choriogenic stage of the ovariol. There are no $\mathrm{mBPB}$ stained blue yolk granules in the ooplasm. *, mBPB negative protein yolks; F, follicular epithelium; arrows, chorion (LM image, mBPB staining, scale bar= $0.02 \mathrm{~mm}$ ).

The proteins, lipids, and carbohydrates deposited in the oocyte during the maturation of the egg (Shende \& Masram, 2020). These storing occur in storage granules founded in the ooplasm of the oocytes, and the ooplasmic granules start to show up in the oocytes in the beginning stages of the development (Anholeto et al., 2018; Shende \& Masram, 2020). These stored granules, called as the yolk granules, give on to quick growth of the oocytes (Shende \& Masram, 2020).

It is known that the carbohydrates are synthesized in the ovary as glycogen and used during the growing of the oocyte (Hilker \& Meiners, 2008; Sanjayan, 2018). With the PAS staining was used which determines mucosubstances, the yolk granules in the ooplasm gave a PAS-positive reaction, and consequently, it was deduced that the content of the yolk granules is carbohydrates. Although carbohydrate yolks were observed in large quantities only during the later stage of vitellogenesis in ooplasm, the mechanism of its formation starts during the earliest stages. This shows that more carbohydrates are needed at the last stage of egg formation.

In the histochemical observations to demonstrate the yolk protein, two different BPB stainings were used as $\mathrm{MBPB}$ and BPB. The mercury ions react with acid groups in proteins, causing the yolk granules to turn blue in mBPB. However, we concluded that the proteins were not acidic since the yolk granules were not stained with $\mathrm{mBPB}$ in P. ataturki. Nonetheless, BPB staining was supposed to turn blue by reacting with the basic groups in proteins. As a result of the negative control after staining, the yolk proteins in $P$. ataturki were stained blue and it was revealed that these proteins were basic. The appearance of BPB positive staining from the germinal vesicle not folicle cells indicate a source of protein, synthesized by the germinal vesicle in ooplasm.

In the TEM observations, the fact that we encountered the welldeveloped granulated endoplasmic reticulum in the cytoplasm of the follicle cells supports the conclusion that the formation of the yolk granules is initiated by the granulated endoplasmic reticulum (Roth \& Porter, 1964; Dettlaff \& Vassetzky, 2012).

\section{Conclusion}

In the present study, we revealed the morphology, histology of $P$. ataturki's ovary, and the histochemistry of yolk granules in the oocyte cytoplasm. We hope that our results will contribute to further studies.

Acknowledgments. We express our thanks to Prof. Dr. Mustafa ÜNAL (Bolu Abant Izzet Baysal University, Faculty of Arts and Sciences, Biology Department) for helping with the species diagnosis and to Gazi University Academic Writing and Research Center for their help and support in the proofreading of the current study.

\section{References}

Anholeto LA, de Oliveira PR, Rodrigues RAF, Yamane LT, Castro KNDC \& Camargo-Mathias MI (2018). Morphological alterations in the ovaries of Amblyomma cajennense semi-engorged ticks exposed to ethanolic extract of Acmella oleracea. Microsc Res Tech 81(11), 1347-1357.

Brundo MV, Longo G, Sottile L, Trovato M, Vitale D \& Viscuso R (2011). Morphological and ultrastructural organization of the spermatheca of some Tettigoniidae (Insecta, Orthoptera). Ital J Zool 78(1), 53-62.

Dettlaff TA \& Vassetzky SG (2012). Oocyte Growth and Maturation. New York: Plenium Press.

Gaino E \& Fava A (1995). Egg general morphology and eggshell fine organization of the grain weevil Sitophilus granarius (L.) (Coleoptera: Curculionidae). Entomologica (Bari) 29, 87-98.

García-Navas V, Noguerales V, Cordero PJ \& Ortego J (2017). Ecological drivers of body size evolution and sexual size dimorphism in short-horned grasshoppers (Orthoptera: Acrididae). J Evol Biol 30(8), 1592-1608.

Giuffrida A, Focarelli R, Lampariello R, Thole H \& Rosati F (1996) Purification and properties of a $35 \mathrm{kDa}$ glycoprotein from spermathecal extract of Eyprepocnemis plorans (Insecta, Orthoptera) with axonemal cytoskeleton disassembly activity. Insect Biochem Mol Biol 26(4), 347-354.

Giuffrida A \& Rosati F (1993). Changes in sperm tail of Eyprepocnemis plorans (Insecta, Orthoptera) as a result of in vitro incubation in spermathecal extract. Invertebr Reprod Dev 24(1), 47-52.

Gnatzy W, Volknandt W \& Dzwoneck A (2018). Egg-laying behavior and morphological and chemical characterization of egg surface and egg attachment glue of the digger wasp Ampulex compressa (Hymenoptera, Ampulicidae). Arthropod Struct Dev 47, 74-81.

Heller KG (2004). Poecilimon martinae sp. $\mathrm{n}$ and P. inflatus Brunner von Watternwyl, 1891 (Orthoptera, Tettigonioidae, Phaneropteridae), two bushcricket species endemic to southwest Anatolia: Morphology, bioacoustics and systematics. Articulata 19(1), 1-17.

Heller KG \& Sevgili H (2005). Systematics and bioacoustics of the Poecilimon sanctipauli-group (Orthoptera: Tettigonioidea: Phaneropteridae). Eur J Entomol 102, 265-277.

Hilker M \& Meiners T (2008). Chemoecology of Insect Eggs and Egg Deposition. Berlin-Vienna: Blackwell Publishing.

Karaca İ, Aslan B, Demirözer O \& Karsavuran Y (2006). Isparta ili Orthoptera faunası üzerine ön bir değerlendirme. Süleyman Demirel Üniversitesi Ziraat Fakültesi Dergisi 1(2), 49-52.

Klowden MJ (2013). Physiological Systems in Insects, 3rd ed. London: Elsevier.

Lange AB (1990). The presence of proctolin in the reproductive system of Rhodnius prolixus. J Insect Physiol 36(5), 345-351.

Lange AB (2009). The female reproductive system and control of oviposition in Locusta migratoria migratorioides. Can J Zool 87, 649-661.

Masci VL, Di Luca M, Gambellini G, Taddei AR, Belardinelli MC, Guerra L, Mazzini M \& Fausto AM (2015). Reproductive biology in Anophelinae mosquitoes (Diptera, Culicidae) fine structure of the female accessory gland. Arthropod Struct Dev 44, 378-387.

Mead LJ, Khachatourians GG \& Jones GA (1988). Microbial ecology of the gut in laboratory stocts of the migratory grasshopper, Melanoplus sanguinipes (Fab.) (Orthoptera: Acrididae). Appl Environ Microbiol 54(5), 11741181.

Michel AA \& Terán HR (2005). Morphological analysis of the female reproductive system in Baeacris punctulatus (Orthoptera, Acrididae, Melanoplinae). Rev Soc Entomol Arg 64(3), 107-117.

Nandchahal N (1972). Reproductive organs of Gryllodes sigillatus (Walker) (Orthoptera: Gryllidae). J Nat Hist 6, 125-131. 
Pappalardo AM, D'Urso V, Viscuso R, Ferrrito V, Giunta MC, Cupani S \& Vitale DGM (2016). Morphostructural investigations of the female reproductive system and molecular evidence for Wolbachia in Balclutha brevis Lindberg 1954 (Hemiptera, Cicadellidae). Micron 81, 23-33.

Polat I (2016). The ultrastructural features of the digestive, excretory, female and male reproductive systems of Poecilimon cervus Karabağ, 1950. PhD thesis. Gazi University, Science Institute (in Turkish).

Roth TF \& Porter KR (1964). Yolk protein uptake in the oocyte of the mosquito Aedes aegypti L. J Cell Biol 20(2), 313-332.

Şahin İ, Bitmiş K \& Erman O (2004). Pezodrymadusa lata (Orthoptera: Tettigoniidae)'nın dişi üreme sistemindeki anatomik ve histolojik yapısı. Firat Üniversitesi Fen ve Mühendislik Bilimleri Dergisi 16(1), 17-24.

Sanjayan KP (2018). Physiology of insect reproduction. In Insect Physiology, Anantanarayanan Raman (Ed.), pp. 343-413. Tamil Nadu, India: Scientific Publisher

Schultner E, Blanchet E, Pagès C, Lehmann GU \& Lecoq M (2012). Development, reproductive capacity and diet of the Mediterranean grasshopper Arcyptera brevipennis vicheti Harz 1975 (Orthoptera: Caelifera: Acrididae: Gomphocerinae). Ann Soc Entomol Fr 48(3-4), 299-307.

Sevgili H (2001). A new bushcricket species and notes on some less known species of the genus Poecilimon fischer, 1853 from Turkey (Orthoptera, Phaneropterinae). J Orthop Res 10(1), 15-24.

Shende B \& Masram S (2020). Histological and histochemical changes in oocytes during oogenesis in Orthetrum sabina (Drury 1770) (Anisoptera: Libellulidae). J Entomol Zool 8(2), 275-281.
Sturm R (2005). Motoric activity of the receptacular complex in the cricket Teleogryllus commodus (Insecta: Orthoptera: Gryllidae). Entomol Abh 62(2), 185-192.

Sturm R (2012). Morphology and ultrastructure of the accessory glands in the female genital tract of the house cricket, Acheta domesticus. J Insect Sci 12(1), 99.

Sturm R \& Pohlhammer K (2000). Morphology and development of the female accessory sex glands in the cricket Teleogryllus commodus (Saltatoria: Ensifera: Gryllidae). Invertebr Reprod Dev 38(1), 13-21.

Taylor BJ \& Whitman DW (2010). A test of three hypotheses for ovariole number determination in the grasshopper Romalea microptera. Physiol Entomol 35(3), 214-221.

Tazegül E \& Önder F (2012). İzmir ilinde bulunan tettigoniidae (Orthoptera) familyası türleri üzerinde sistematik araştırmalar. Turk Bull Entomol 2(2), 109-123.

Vahed K (2003). Structure of spermatodoses in shield-back bushcrickets (Tettigoniidae, Tettigoniinae). J Morphol 257, 45-52.

Viscuso R, Narcisi L \& Sottile L (1999). Structure and function of seminal vesicles of Orthoptera Tettigonioidea. Int J Insect Morphol Embryol 28, 169-178.

Willis JD, Klingeman WE, Oppert C, Oppert B \& Jurat-Fuentes J (2010). Characterization of cellulolytic activity from digestive fluids of Dissosteira carolina (Orthoptera: Acrididae). Comp Biochem Physiol B 157, 267-272.

Yılmaz I, Suludere Z \& Candan S (2012). Poecilimon cervus Karabağ (Orthoptera: Tettigoniidae) yumurta yapısı ve ultrastrüktürel özellikleri. Türkiye Entomoloji Dergisi 36(4), 549-556. 